\title{
The Florida Community College Statewide Collection Assessment Project: Outcomes and Impact
}

\author{
Anna H. Perrault, Tina M. Adams, Rhonda Smith, and \\ Jeannie Dixon
}

\begin{abstract}
A collection assessment project was conducted in 1998 of the twentyeight community college library/Library Resource Center (LRC) collections in Florida. ${ }^{1}$ The evaluative materials provided to each of the institutions produced a number of outcomes. To assess the project's impact, a survey was conducted in fall 2000 . The impact study found that, in the opinion of library administrators, the Florida Community College Collection Assessment study had influenced the appropriation of additional funds, informed librarians' collection development decisions, and affected the weeding of collections through the presentation of institution-specific collection assessment reports that were provided for each library. The major finding of the impact study was that the additional funding for community college library acquisitions, passed by the Florida legislature in 1999, was not wholly successful in the revamping of outdated book collections because many of the Florida community college libraries received only part or none of the funding. The utilization of the project data, the findings of the impact study, and other follow-up to the project are reported in this article.
\end{abstract}

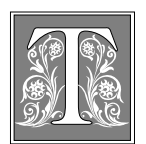

he College Center for Library Automation (CCLA) was established in 1988 to provide a statewide library automation system for all twenty-eight community colleges in Florida. From the beginning, CCLA has fulfilled that mission through Library Information Network for Community Colleges (LINCC), the statewide network. CCLA also provides a full range of network services, including consulting and training for all new modules and upgrades. A number of committees and task forces composed of administration and staff from the community college LRCs have made recommendations for the development of the database and network services. In recent years, CCLA has been in the forefront in providing a Web-based interface with a range of databases selected

Anna H. Perrault is an Associate Professor of Library and Information Science at the University of South Florida; e-mail: perrault@chuma1.cas.usf.edu. Tina M. Adams is a Reference Librarian in the Cline Library at Northern Arizona University; e-mail: Tina.Adams@nau.edu. Rhonda Smith is the Reference/ Instruction Librarian at Lake Sumter Community College; e-mail: smithr@lscc.cc.fl.us; Jeannie Dixon is the Data Migration Coordinator at the College Center for Library Automation e-mail: J.Dixon@ccla.lib.fl.us. 
by the CCLA Information Portal Committee. The administration of CCLA was instrumental in securing state funding for the database package, a distance reference and referral center, and a statewide courier service. New services added in 20002001 include "My Account" through which students can view their personal circulation data and renew items online. In addition to the database package, e-book titles are provided through purchase by CCLA and are free to all the community colleges.

Under CCLA sponsorship, a comprehensive collection assessment project of community college library/LRC monographic collections was completed in 1998. ${ }^{2}$ The purpose of the project was to provide statewide comparative data to community college librarians and administrators. The study was conducted with data extracted from LINCC, the online database of the College Center for Library Automation. The study report analyzed the aggregated resources base of the community colleges as reflected in the LINCC database. Each individual community college library/LRC collection was then compared with the aggregated database and peer institutions within Florida.

In the collection assessment project, each Florida community college LRC's monograph collection was evaluated and collection assessment reports for each institution were developed to provide collection development librarians with documentation of subject strengths and particular weaknesses in their library's collections. The collection assessment reports included an analysis of shifts in collection patterns by time period, proportions of subjects by time period, a report on the median age of the library's collection by subject, a summary ranking each library's collection based on median age of monographs within the Florida community college system, and recommendations.

The major finding was that the monographic collections of Florida community colleges were significantly out of date with the majority of library books having been published before the 1970s. In addition, it was found that in the 1990s, the percent- age of older materials to newer materials had increased and that outdated materials were prevalent in all major subject divisions, including science and technology. ${ }^{3}$

The results of the assessment were given to each community college in a series of workshops conducted by CCLA in fall 1998. Each college received a copy of a full report on the monograph holdings as reflected in LINCC and a report for the monographic holdings of the individual institution with comparative analysis by peer group.

Because the role of community college libraries is to support the curriculum and to provide primarily for the research needs of lower-division undergraduates rather than those of more advanced students and scholars, the currency of the collections is extremely important. In fiscal year 1999, the base budget of the Florida Division of Community Colleges was increased by the Florida legislature with the expressed intention of updating the collections of community college libraries. Community colleges in Florida are independent with their own governing boards, and there were no provisions for requiring the community college administrations to pass the funds on to the libraries. The hope was that the collection assessment reports, along with the additional funding by the Florida legislature, would allow Florida community colleges to update their monograph collections appropriately. Although there was anecdotal evidence that the collection assessment project was highly regarded and had been well received by community college librarians, those responsible for the study wanted to have documentation as to the perceived benefits of the project. It was decided that an impact study would be conducted to obtain formal input on the use of the results of the collection assessment project.

\section{Purpose of the Impact Study}

The purpose of the impact study was twofold:

- to ascertain the extent of the utilization of the reports from the Florida Community College Assessment project by the librarians for collection management; 
- to ascertain the use of the funds from the special legislative appropriations.

Specific questions to be answered were:

- Had the Florida Community College Library Collections Report informed collection development decisions?

- Did the results of the study have an effect on the weeding of collections?

- On what curricular areas were the funds from the special legislative appropriations spent?

- What influence did the collection assessment report have on securing the special legislative appropriations?

\section{Review of Related Research}

The majority of the literature and research on academic libraries focuses on research libraries or libraries in four-year institutions. The body of literature that focuses on community college collections is limited. The most comprehensive and recent studies have been those conducted in Florida. A study in the mid-1990s, "An Assessment of the Collective Resources Base of Florida Community College Library Collections," reported on the profile of the aggregated statewide collection of Florida community college resources using data extracted from the Florida community colleges shared online cata$\log$, LINCC. ${ }^{4}$ That report contains a review of the literature on analysis of community college collections.

The first study of the Florida community college aggregated resources base was a pilot to determine the feasibility of analyzing the holdings of the LINCC database and the community college collections individually. The purpose of the project was "to provide baseline data for future collection assessments, to promote the routine provision of collection analysis for libraries, to contribute to the establishment of norms for community college collections, and to use collection assessment as a force for establishing the need for increased funding for community college libraries." ${ }^{\prime 5}$

Based on the learning experience of the first project, a more extensive study of
Florida community college monograph collections was conducted in 1998. Data were extracted for the LINCC aggregated collection and the individual collections of all twenty-eight community colleges in Florida in March 1998. This second project is the most comprehensive statewide assessment of community college collections that has been reported. ${ }^{6}$ The major focus on the study's findings are the analysis by median age by subject for each of the twenty-eight LRCs and the aggregated resources base. The problem of median age was the subject

of an article in College $\mathcal{E}$ Research Libraries, "The Effects of High Median Age on Currency of Resources in Community College Library Collections." ${ }^{\prime 7}$ The article focused on the mission for community colleges to emphasize the instructional and curricular needs of students through the provision of current materials. The researchers presented the findings from the Florida Community College Library Collections study to illustrate that many college library collections at the end of the twentieth century had high median ages in monographic resources, particularly in the professional, scientific, and technical fields. The adoption of a Continual Update Collection Management Model that proposed adding new materials at 5 percent per year while withdrawing outdated materials at 5 percent per year was recommended in the CERL article. If such a model were adopted, as new materials are added and older, outdated materials are withdrawn, the median age of resources will remain within an acceptable range, resulting in a current and viable collection. ${ }^{8}$ Although it would have been interesting to note, there appears to be no body of literature in existence that discusses community college libraries and internal institutional politics or the community colleges' libraries' relations with administrative bodies. 
A publication that somewhat relates to this study's topic concerning community colleges and funding is "Learning Resource Centers in Community Colleges: A Study of Budgets and Services," which studied the problem of how funding affects the provision of services in community college libraries. ${ }^{9}$ This study was conducted in twenty-seven community colleges across several states, including two in Florida. Data were collected by interviewing library directors and other key personnel. The study revealed a correlation between library services and funding. Specifically, the college libraries experiencing a definite downward trend in their budgets reported being unable to develop their services and grow as they had planned. ${ }^{10}$ Though dated, the results of the study probably are still reflective of current practice.

The impact study reported here addresses, in part, the issue of funding for the Florida community college collections.

\section{Methodology}

A survey was sent to the twenty-eight Florida community college library directors and/or collection development librarians in spring 2001. Its purpose was to ascertain whether the 1998 Florida Community College Collection Assessment Report and the article derived from it, "The Effects of High Median Age on Currency of Resources in Community College Library Collections," were instrumental in securing the additional funding, which was passed in May of 1999 as part of the Division of Community Colleges budget by the Florida legislature. ${ }^{11,12}$ The survey sought to learn whether each library received the allotted funding from its college as intended and, if so, what materials were purchased with the funding; whether the library spent this money on the collection; whether the library spent it on monographs, and if so, what subject areas; and whether the results of the collection assessment study were used as a guide when selecting materials.
Data collection was conducted via a Web survey. A follow-up question was sent via e-mail to each director who returned the survey. The follow-up question was concerned specifically with finding out from those libraries that had reported not receiving any additional funding whether they were informed of the reason they did not receive it and from those libraries that did receive part or all of the additional funding, what amount was received.

\section{Analysis of Results}

In Florida, the twenty-eight community colleges are traditionally divided into three groups, based on size of the institution by enrollment. Group 1 is composed of large community colleges, group 2 of medium-sized community colleges, and group 3 of the smaller community colleges. These divisions were used to ascertain whether size had any effect on either the libraries' ability to garner the funding from their institution or the libraries' collection development choices. It could not be established from the results that size was, in any way, a factor.

Of the twenty-eight library directors surveyed, twenty-three, or 82 percent, responded, but only twenty-one answered all the questions. The survey response rate for each size group varied. The larger the library group, the greater the response rate. Group 1, the largest institutions, had a 100 percent response rate; group 2, the medium-sized institutions, had a 78 percent response rate; and group 3, the smallest institutions, had a 70 percent response rate.

\section{Administrative Questions}

Of the twenty-three responses received, twelve respondents felt that the Florida Community College Collection Assessment study had a profound effect on the Florida legislature's willingness to appropriate additional funding for the purpose of updating the currency of the monograph collections. Eight of the respondents felt that the study had at least some effect on the passing of the funding, and only two felt that it had little effect or were 
unsure of the effect. Overall, the majority of respondents felt that the study produced positive results and helped secure the additional funding.

In addition, 100 percent of the respondents reported that the College Library Collection Assessment Report informed their collection development decisions. All but two of the respondents replied that the results of the collection assessment study affected the weeding of their collections. One of these two respondents was quick to point out that it did have the effect of showing how badly the collection needed to be weeded.

\section{Funding Question}

Of the twenty-two responses to the question concerning the amount of funding received, seven of the libraries received all of the additional funding as promised, eight received at least part of it, and seven received none. Only nineteen of the twenty-eight directors, or 69 percent, responded to the follow-up question regarding actual dollar figures.

Two libraries, one that received all of the funding and one that received only part of it, were informed by their administrations that the money was to be used to purchase new computers only and not to be used for the collection. (See table 1, LRC 2 and LRC 15.)

One library had previously not been allocated money for a book budget, and although the library received all the funding $(\$ 30,000)$ from the special appropriation, because no funding had previously been allocated for monographs, the $\$ 30,000$ made up the entire book budget for that year. (See table 1, LRC 19.)

In addition, in one instance the LRC received all of the additional funding $(\$ 80,000)$, but instead of augmenting the budget, the additional funding in fact replaced the previous book budget, which subsequently went down to $\$ 40,000$ the following year. Thus, no additional funding was added to the budget; instead, the budget was reduced for the upcoming fiscal year. Concerning the follow-up question, which sought to discover how much of the funding intended for book replacement in Florida community colleges actually reached the libraries, nineteen out of the twenty-eight libraries, or 68 percent, responded to the follow-up question. This left nine libraries that responded to the survey but did not report a dollar figure.

Of the $\$ 5$ million allocated by the Florida legislature, only $\$ 1,808,500$ could be identified as having gone to the library budget. Although not all college libraries reported their figures, seven of the nine largest libraries did for a total of $\$ 1,377,500$. Considering that the amount of funding was allocated based on the size of existing collections, with the largest libraries slated to receive the most money, it could be conjectured that a majority of the $\$ 5$ million allocated to book replacement in the 1999 legislative budget for community college libraries did not, in fact, reach the libraries. A definitive answer cannot be reached because not every library reported the amount of funds received.

Table 1 shows response rates to the survey, response rates to the follow-up question, and the amount of additional funding received by each library, although not all libraries reported. It should be noted that in cases in which a dollar figure is given, there may be special comments associated with it. These cases are denoted by a unique symbol following the figure and explained in the caption located beneath the table.

\section{Collection Questions}

For those libraries that received the additional funding, the respondents were asked to estimate what percentages of the funds were spent on the collection, equipment, or other expenses. Table 2 shows the libraries divided into size groups. Of the fifteen libraries that reported receiving at least some funding, nine spent 100 percent of the money on the library collection. Two libraries reported spending all of the funding on equipment. (Again, these were the two libraries mentioned earlier that were informed that the money was to be used to purchase new computers only and not 
TABLE 1

Response Rates and Reported Dollar Figures

\begin{tabular}{|c|c|c|c|c|}
\hline Institution & Size Group & Survey Reply & Follow Up & Dollar Figure \\
\hline LRC 1 & 1 & $\mathrm{Y}$ & $\mathrm{Y}$ & $\$ 300,000$ \\
\hline LRC 2 & 1 & $\mathrm{Y}$ & $\mathrm{Y}$ & $\$ 30,000 \bullet$ \\
\hline LRC 3 & 1 & $\mathrm{Y}$ & $\mathrm{Y}$ & $\$ 250,000$ \\
\hline LRC 4 & 1 & $\mathrm{Y}$ & NA & 0 \\
\hline LRC 5 & 1 & $\mathrm{Y}$ & & $\mathrm{U}$ \\
\hline LRC 6 & 1 & $\mathrm{Y}$ & NA & 0 \\
\hline LRC 7 & 1 & $\mathrm{Y}$ & & $\mathrm{U}$ \\
\hline LRC 8 & 1 & $\mathrm{Y}$ & $\mathrm{Y}$ & $\$ 560,000$ \\
\hline LRC 9 & 1 & Y & $\mathrm{Y}$ & $\$ 237,500$ \\
\hline \multicolumn{2}{|c|}{ Total Responses (1) } & $9 / 9(100 \%)$ & $7 / 9$ & $7 / 9$ \\
\hline \multicolumn{4}{|c|}{ Group 1Total Dollar Figure Reported } & $\$ 1,377,500$ \\
\hline LRC 10 & 2 & $\mathrm{~N}$ & & $\mathrm{U}$ \\
\hline LRC 11 & 2 & $\mathrm{~N}$ & & $\mathrm{U}$ \\
\hline LRC $12 \dagger$ & 2 & $\mathrm{Y}$ & & $\mathrm{U}$ \\
\hline LRC 13 & 2 & $\mathrm{Y}$ & $\mathrm{Y}$ & $\$ 40,000$ \\
\hline LRC 14 & 2 & $\mathrm{Y}$ & NA & 0 \\
\hline LRC 15 & 2 & $\mathrm{Y}$ & $\mathrm{Y}$ & $\$ 26,000 \bullet$ \\
\hline *LRC 16 & 2 & $* \mathrm{Y}$ & NA & NA \\
\hline LRC 17 & 2 & $\mathrm{Y}$ & $\mathrm{Y}$ & 0 \\
\hline LRC 18 & 2 & $\mathrm{Y}$ & & $\mathrm{U}$ \\
\hline \multicolumn{2}{|c|}{ Total Responses (2) } & $7 / 9(78 \%)$ & $5 / 9$ & $5 / 9$ \\
\hline \multicolumn{4}{|c|}{ Group 2 Total Dollar Figure Reported } & $\$ 66,000$ \\
\hline LRC 19 & 3 & $\mathrm{Y}$ & $\mathrm{Y}$ & $\$ 30,000 \S$ \\
\hline LRC 20 & 3 & $\mathrm{Y}$ & NA & 0 \\
\hline LRC 21 & 3 & $\mathrm{~N}$ & & $\mathrm{U}$ \\
\hline LRC 22 & 3 & $\mathrm{Y}$ & $\mathrm{Y}$ & $\$ 100-110,000$ \\
\hline LRC 23 & 3 & $\mathrm{Y}$ & NA & 0 \\
\hline LRC 24 & 3 & $\mathrm{Y}$ & $\mathrm{Y}$ & $\$ 80,000 \div$ \\
\hline LRC 25 & 3 & $\mathrm{Y}$ & $\mathrm{Y}$ & $\$ 145,000$ \\
\hline LRC 26 & 3 & $\mathrm{Y}$ & NA & 0 \\
\hline LRC 27 & 3 & $\mathrm{~N}$ & & $\mathrm{U}$ \\
\hline LRC 28 & 3 & $\mathrm{~N}$ & & $\mathrm{U}$ \\
\hline \multicolumn{4}{|c|}{ Group 3 Total Dollar Figure } & $\$ 365,000$ \\
\hline \multirow{4}{*}{\multicolumn{3}{|c|}{$\begin{array}{l}\text { Total Responses (3) } \\
\text { Grand Total } \\
\text { Grand Total \$ Amount } \\
\text { Amt Funded by Legislature }\end{array}$}} & $7 / 10$ & $7 / 10$ \\
\hline & & & & $19 / 28$ \\
\hline & & & & $\$ 1,808,500$ \\
\hline & & & & $\$ 5,000,000$ \\
\hline \\
\hline \multicolumn{5}{|c|}{ * This survey was returned blank-New Director-did send comments } \\
\hline \multicolumn{5}{|c|}{$\$$ Replaced previous book budget. Following year received only $\$ 40,000$} \\
\hline \multicolumn{5}{|c|}{ - Could only spend on computers } \\
\hline \multirow{2}{*}{\multicolumn{5}{|c|}{$\begin{array}{l}\S \text { Original book budget was } \$ 0 \text {. The library now has } \$ 30,000 \text { due to the funding. } \\
\text { U Unreported }\end{array}$}} \\
\hline & & & & \\
\hline
\end{tabular}


TABLE 2

LRCs Receiving Funding: \% of Additional Funding Spent on Each Area

\begin{tabular}{|c|c|c|c|c|c|}
\hline & $\begin{array}{c}\text { Received } \\
\text { Any Funding }\end{array}$ & $\begin{array}{c}\text { Print } \\
\text { Monographs }\end{array}$ & $\begin{array}{l}\text { Audio } \\
\text { Visual }\end{array}$ & $\begin{array}{l}\text { Print } \\
\text { Serials }\end{array}$ & $\begin{array}{l}\text { Electronic } \\
\text { Products }\end{array}$ \\
\hline \multicolumn{6}{|l|}{ Group 1} \\
\hline LRC 1 & Yes & $75 \%$ & $20 \%$ & & $5 \%$ \\
\hline LRC $2 \dagger$ & Yes & 0 & 0 & 0 & 0 \\
\hline LRC 3 & Yes & $80 \%$ & $15 \%$ & 0 & 5 \\
\hline LRC 4 & No & & & & \\
\hline LRC 5 & Yes & NA & NA & NA & NA \\
\hline LRC 6 & No & & & & \\
\hline LRC 7 & Yes & $85 \%$ & $5 \%$ & $5 \%$ & $5 \%$ \\
\hline LRC 8 & Yes & $90 \%$ & $10 \%$ & & \\
\hline LRC 9 & Yes & $79 \%$ & $7 \%$ & $1.6 \%$ & $12.6 \%$ \\
\hline \multicolumn{6}{|l|}{ Group 2} \\
\hline LRC 10 & Yes & $95 \%$ & $5 \%$ & & \\
\hline LRC 11 & Yes & $100 \%$ & & & \\
\hline LRC 12 & No & & & & \\
\hline LRC 13 & Yes & 0 & 0 & 0 & 0 \\
\hline LRC 14 & No & & & & \\
\hline LRC 15 & Yes & NA & NA & NA & NA \\
\hline \multicolumn{6}{|l|}{ Group 3} \\
\hline LRC 16 & Yes & $75 \%$ & & & $25 \%$ \\
\hline LRC 17 & No & & & & \\
\hline LRC 19 & Yes & $80 \%$ & $20 \%$ & & \\
\hline LRC 20 & No & & & & \\
\hline LRC 21 & Yes & $97 \%$ & $3 \%$ & & \\
\hline LRC 22 & Yes & $95 \%$ & $5 \%$ & & \\
\hline LRC 23 & No & & & & \\
\hline \multicolumn{6}{|c|}{$\begin{array}{l}\text { NA denotes that although this particular library received the funding, it did not answer the } \\
\text { question. } \\
\uparrow \text { Spent } 100 \% \text { on equipment. }\end{array}$} \\
\hline
\end{tabular}

to be allocated to the collection.) Three libraries spent a majority of the funds (between $75 \%$ and $90 \%$ ) on the collection and the rest on equipment. Only one library reported spending any of the funds on expenses outside the areas of the collection or equipment. No correlation between spending decisions and library size could be inferred from the data.

Of the fifteen libraries that received at least some additional funding, eleven reported the areas in which they spent the funds. As table 3 shows, nine of the eleven libraries indicated buying in the area of psychology, philosophy, and religion, as well as in the physical and life sciences, particularly in mathematics and computer studies. Ten of the libraries reporting specified buying in the areas of history and business and management, as well as arts, music and theater, education, and literature and language. All of the eleven libraries reporting, indicated buying in the areas of the social sciences and the vocational health sciences. This may be due to the fact that in addition to using social science resources for social science study, required English composition classes use these resources to write pro and con papers or opinion papers on a 
TABLE 3

Representation of Curricular Areas Where Funding Was Spent from the Fifteen Libraries That Received Any Funding and Reported Spending

Library of Congress

Class Subject Area
Number of Libraries

Spending in this Area

\begin{tabular}{lr}
\hline Psychology, Philosophy, Religion (B) & 9 \\
Social Sciences (C-J) & 11 \\
$\quad$ History & 10 \\
$\quad$ Business \& Management & 10 \\
Law (K) & 7 \\
Education (L) & 10 \\
Arts, Music, Theater (M-N) & 10 \\
Literature, Language \& Communications (P) & 10 \\
Physical \& Life Sciences (Q) & 9 \\
$\quad$ Mathematics & 9 \\
Computer Studies & 9 \\
Vocational Health Sciences (R) & 11 \\
Industrial \& Vocational Technology (S-T) & 9
\end{tabular}

current controversial issue. The area with the least amount of purchases was law, with only seven of the eleven libraries buying in this area.

The comments received in the survey were very helpful in assessing the effectiveness of the collection assessment project. Most of the responses concerning the study's usefulness indicated that not only did the librarians themselves find it useful for weeding and becoming aware of the areas that needed strengthening, but the study quantified and reinforced what community college collection librarians and administrators had been asserting all along-that the libraries were underfunded.

Some respondents admitted to being shocked when finding out about the age of their collections, but many attest to knowing that, in general, their collections were outdated. One respondent stated: "We knew we were out of date, but this laid it on the line. It also let our administrators know that it wasn't only us that were saying our collection was very dated. When the whole state can see, it makes a big difference."

Many of the directors surveyed felt that even though they did not receive the additional funding appropriated by the legis- lature, the study was important to community college libraries in that it helped each library, through the provision of the institution-specific collection reports, to prioritize areas to weed and concentrate their regular collection development efforts.

In short, as many of the respondents stated, the study provided quantitative and objective data that could be submitted to administrators. As one library administrator wrote, "it provided justification information for students and library committee[s] to lobby for additional funding to be given to the library."

\section{Other Outcomes and Follow-up}

In the three years since the results of the Florida Community College Collection Assessment were given to the twentyeight community college library directors, the CCLA's administration and various standing committees have initiated a number of other projects that are related to the study. The foremost of these is an inventory project that all twenty-eight colleges conducted. Using the LINCC collection inventory software, nearly two million items were inventoried. CCLA provided training in the use of the software and detailed inventory reports. For most of the collections, this was the first 
inventory since coming online with the LINCC system.

Those involved in the study looked at reports from the LINCC system to see if the changes taking place in the management of the collections could be discerned through changes in reported data. As of December 1998, there were 3,149,995 item records for 949,077 MARC records. As of August 2001, there were 3,360,548 item records for 1,035,720 MARC records. In this time span, there was an increase of

\section{The Florida College Center for Library Automation went beyond the mere provision of routine data reports.}

more than 210,000 items, an average of 10,259 a month, which is a little higher than the normal monthly average of 6,000 to 7,000 . The increase in bibliographic records is an average of 4,322 a month; in the past, the average was close to $4,000 \mathrm{a}$ month. These figures point to an above average rate of additions in records to the LINCC database.

From academic year 1999-2000 to 2000-2001, there was an increase in circulation through the system of nearly 200,000 items. Enrollment had increased in the latest year, but it was hoped that the steps being taken to weed and increase new current materials might have influenced the increase in circulation.

Another area to gauge increased use and the strength of community college collections was interlibrary loan (ILL) statistics. Although lending levels for 19981999 and 1999-2000 were nearly even at 28,160 and 28,133, respectively, borrowing activity within the community college system increased by 7 percent, or 1,741 items. ${ }^{13}$ In part, this may reflect increased student awareness of the availability of ILL loan services. In addition, it is important to note that at least 36 percent of all materials borrowed in 1999-2000 were borrowed within the community college system at an increase of 4 percent over the previous year. It is possible that the increase can be attributed to the addi- tional funding at least some community college libraries received for materials. The presence of more current materials within the system may have led to an increase in ILL borrowing. ${ }^{14}$ Other factors in increased ILL borrowing are the establishment of a statewide courier system and, beginning in 2001, direct requests by individuals for interlibrary loans within the LINCC system.

In fall 2001, the parties responsible for conducting the Florida Community College Collection Assessment project met to discuss its impact on the collections. In the period of three years, many changes had occurred in the Florida higher education arena. The establishment of a "seamless," one-board governance for all of education in Florida was bringing about sweeping change. The two systems of higher education in the state each had a library system for their member institutions.

Signals were coming from the new board that a common library system should be purchased jointly by both of the higher education systems. In light of these looming changes, it was decided to conduct another interval to the Florida Community College Collection Assessment with data extraction in March 2002. The collection assessment in 1998 will serve as baseline data for the study in 2002 .

A circulation study matching the data elements by subject and by age will be added to the collection assessment. It is anticipated that the changes in the collections that came about as a result of the collection assessment project will show in different collection profiles with more current materials, a lowered median age, and high circulation in recent materials.

\section{Summary and Conclusions}

The impact study found that in the opinion of Florida community college library administrators, the Florida Community College Collection Assessment study did influence the appropriation of the additional funds, informed librarians' collection development decisions, and affected the weeding of collections through the presentation of institution-specific collec- 
tion assessment reports that were given to each library. The reports provided to the community colleges had a local impact in that twenty-one out of the twentyeight used them in weeding and collection development. There is agreement that the reports were a direct influence on the request made to the Florida legislature by the Division of Community Colleges for special appropriations to address the lack of current materials as shown by the data analysis in the study.

But, unfortunately, one of the findings of the impact study is that the additional funding appropriated by the Florida legislature did not aid in the revamping of outdated book collections because many of the community college libraries received only part or none of the funding. Only seven libraries received the entire amount expected. Where libraries did receive some or all of the funding, the majority of the money was spent on print monographs, as intended, and funding was allotted to all the major fields of study, especially social sciences, health sciences, education, language arts, and the humanities.

As a statewide collection assessment, the objectives of the project were achieved in that the comparative data analysis and interpretation provided to the twentyeight Florida community college library / LRCs was used in collection development decision-making and in justifying funding for the collections.

The Florida Community College Collection Assessment project is an example of the type of value-added services statewide networks and systems can provide for members. Many networks and systems do provide reports by call number range by year of publication. These data are also available for circulation by the same parameters. The Florida College Center for Library Automation went beyond the mere provision of routine data reports. Its administration sought to provide a valueadded service to the member libraries by sponsoring a project that produced comparative reports and data analysis. The results of the collection assessment project were well received, even though the major findings pointed up the weaknesses in the collections. The CCLA administration further used the results of the project by presenting the report to the Division of Community Colleges, thus providing evidence for the legislative requests. The collection assessment project was instrumental in influencing policy at the state level.

\section{Notes}

1. Anna H. Perrault et al., Florida Community College Library Collection Assessment (Feb. 10, 1999). ERIC ED 428773. Florida, U.S.: 1-22, available from http://www.ccla.lib.fl.us/docs/ collassess/state_rpt.pdf.

2. Ibid.

3. Perrault et al., "The Effects of High Median Age on the Currency of Resources in Community College Library Collections," College E Research Libraries 60 no. 4 (July 1999): 316-38.

4. — "An Assessment of the Collective Resources Base of Florida Community College Library Collections: A Profile with Interpretative Analysis," Resource Sharing and Information Networks, 14, no.1 (1999): 3-20.

5. Ibid., 5-6.

6. Perrault et al., ERIC ED 429733.

7. _— "The Effects of High Median Age on the Currency of Resources."

8. Ibid.

9. Sarah Katharine Thomson, Learning Resource Centers in Community Colleges: A Study of Budgets and Services (1975). ERIC ED 118159.

10. Ibid., 45-46.

11. Perrault et al., "The Effects of High Median Age on the Currency of Resources," 319.

12. State of Florida, "1999-2000 General Appropriations and Summary Statement of Intent: Department of Education, Division of Community Colleges," Online Sunshine, section 2.9, no.79 (May 14, 1999), available from http:www.leg.state.fl.us/Welcome/index.cfm.

13. E-mail from CCLA Service Desk to Tina Adams, April 13, 2001.

14. College Center for Library Automation, "CCLA 2000 Resource Sharing Survey" (Mar. 29, 2001): 1-3. 